\title{
TAMBAK TERLANTAR SEBAGAI TEMPAT PERINDUKAN NYAMUK DI DAERAH ENDEMIS MALARIA (Penyebab dan Penanganannya)
}

\author{
Kholis Ernawati*, Umar F. Achmadi**, Tresna P. Soemardi**, Hasroel Thayyib**, dan Sri \\ Mutia $\mathbf{R}^{* * *}$
}

* Mahasiswa Program Doktor Ilmu Lingkungan, Program Pasca Sarjana - Universitas Indonesia, Salemba Jakarta. Dosen Fakultas Kedokteran, Universitas YARSI, Cempaka Putih Jakarta email: kholisernawati@yahoo.co.id

** Dosen Program Pasca Sarjana, Universitas Indonesia, Salemba Jakarta

***Dosen Fakultas Ilmu Komunikasi, Universitas Indonesia, Depok.

\begin{abstract}
ABSTRAK
Penelitian ini bertujuan untuk mengetahui akar masalah munculnya tempat perindukan nyamuk Anopheles sebagai vector malaria, serta permasalahan sosial seputar pengelolaan perindukan nyamuk di daerah endemis malaria. Penelitian dilakukan di Kecamatan Punduh Pedada, Kabupaten Pesawaran, Propinsi Lampung. Focus pengamatan pada tambak terlantar di desa Sukarame, Sukamaju, dan Kampung Baru. Pengumpulan data dilakukan dengan menggunakan kuesioner, in dept interview, pengamatan, dan studi literature. Data dianalisis dengan metode deskriptif kualitatif. Hasil penelitian menunjukkan bahwa persoalan tambak terlantar akibat adanya konflik lahan, perijinan, pendidikan masyarakat yang rendah, kemiskinan serta peran serta masyarakat yang rendah. Penanganan tambak terlantar dimulai dari menumbuhkan kesadaran seluruh individu bahwa malaria merupakan permasalahan yang serius dan penanganan tambak terlantar merupakan keniscyaan untuk memutuskan rantai penularan penyakit. Menghidupkan tambak lagi dengan budi daya udang atau menggantinya dengan ikan nila. Menerapkan prinsip kerjasama lintas sector, integrated, dan sustainability dalam penanganan tambak terlantar.
\end{abstract}

Kata Kunci: Tambak Terlantar, Daerah Endemis Malaria, Tempat Perindukan Nyamuk, Penyebab Munculnya Tambak Terlantar, Penanganan Tambak Terlantar.

\begin{abstract}
This study aims to determine the root causes of the emergence of Anopheles mosquito breeding places as a vector of malaria, and social issues surrounding the management of mosquito breeding in malaria endemic areas. The study was conducted in the District Punduh Pedada, Pesawaran, Lampung. Focus observations on abandoned farms in the village Sukarame, Sukamaju, and Kampung Baru. The data was collected using a questionnaire, in dept interview, observation, and study of literature. Data were analyzed with descriptive qualitative method. The results showed that the issue of farm land have been displaced by the conflict, licensing, public education is low, poverty and low community participation. Handling derelict farm started growing awareness of all individuals that malaria is a serious problem and the handling of abandoned ponds are a must to break the chain of disease transmission. Turning again to the aquaculture pond shrimp or replace it with tilapia. Applying the principle of cross-sector collaboration, integrated, and sustainability in the handling of abandoned farms.
\end{abstract}

Keywords: Abandoned Farms, Malaria Endemic Area, Mosquito Breeding Places, Causes Of Emergence Pond Abandoned, Neglected Pond Management. 


\section{PENDAHULUAN}

Eliminasi malaria menjadi salah satu goal Millenium Development Goals (MDGs) yang dicanangkan dicapai pada 2015 disepakati pada konferensi tingkat tinggi (KTT) Millenium Perserikatan Bangsa-bangsa pada September 2000, yaitu: (a) eradicate extreme poverty and huger; (b) achieve universal primary education; (c) promote gender equality and empowerment; (d) reduce child mortality; (e) improve maternal health; (f) combat HIV/AIDS, malaria and other diseases; ( $g$ ) ensure environtmental sustainability; (h) develop a global partenrship for development. Malaria menjadi salah satu penyakit yang mendapat perhatian khusus karena malaria adalah salah satu penyakit menular yang masih menjadi masalah kesehatan masyarakat di dunia termasuk Indonesia. Penyakit ini mempengaruhi tingginya angka kematian bayi, balita dan ibu hamil. Setiap tahun lebih dari 500 juta penduduk dunia terinfeksi malaria dan lebih dari 1.000.000 orang meninggal dunia. Kasus terbanyak terdapat di Afrika dan beberapa negara Asia, Amerika Latin, Timur Tengah dan beberapa bagian negara Eropa (Departemen Kesehatan RI, 2009).

Dampak yang luar biasa dari malaria menimbulkan masalah sosial yang pelik. Permasalahan sosial ekonomi yang ditimbulkannya kadang tidak kalah serius dari permasalahan kesehatan itu sendiri. Menurut Sutisna (2004), di daerah endemis malaria, malaria akan menurunkan taraf hidup manusia, terutama anak-anak, ibu hamil dan menyusui serta menurunkan produktivitas dan kualitas sumber daya manusia.

Malaria merupakan penyakit infeksi yang disebabkan oleh parasit Plasmodium. Penyakit ini disebarkan oleh nyamuk Anopheles betina dan perkembang-biakannya sangat tergantung pada faktor lingkungan setempat, kedekatan antara lokasi perkembang-biakan nyamuk dengan manusia dan jenis nyamuk di wilayah tersebut (Clive, 2002). Peningkatan suhu bumi akan meningkatkan jumlah vector borne disease dan terjadinya transmisi penyakit. Perubahan iklim akan memiliki dampak jangka panjang dan jangka pendek terhadap transmisi malaria (Githeko et al, 2000). Malaria selain dipengaruhi oleh perubahan lingkungan global (perubahan iklim) juga dipengaruhi perubahan lingkungan lokal (Achmadi, 2009).
Berbagai kegiatan manusia dalam pembangunan seperti kegiatan tambak yang terlantar, pembangunan bendungan, penambangan timah, dan pembukaan lahan untuk pertanian dan peternakan menyebabkan perubahan lingkungan yang menyebabkan timbulnya tempat perindukan nyamuk buatan manusia (man made breeding places) (Departemen Kesehatan RI, 2007).

Pengendalian vektor malaria melalui pengelolaan lingkungan perindukan tercantum secara eksplisit dalam Kepmenkes RI No. 239/MENKES/SK/IV/2009 tentang Eliminasi Malaria Di Indonesia. Dalam Kepmenkes tersebut kegiatan pengelolaan lingkungan perindukan nyamuk malaria direkomendasikan pada tahap pra eliminasi dan eliminasi. Pada tahap pra eliminasi, salah satu kegiatan yang direkomendasikan adalah "Melakukan pengendalian vektor dengan metode lain yang sesuai untuk menurunkan reseptivitas, seperti manajemen lingkungan, larvasida, dan pengendalian vektor secara hayati". Sedangkan pada tahap eliminasi disebutkan "Bila perlu melakukan larvasida atau manajemen lingkungan dilokasi fokus yang reseptivitasnya tinggi (kepadatan vektor tinggi dan adanya faktor lingkungan serta iklim yang menunjang)".

Kegiatan tambak udang selain menghasilkan keuntungan ekonomi, ternyata juga menyisakan banyak persoalan manakala kegiatan tambak tidak lagi dilanjutkan. Salah satu dampak dari kegiatan tambak yang tidak lagi produktif atau terlantar adalah menjadi tempat perindukan nyamuk Anopheles. Seperti yang terjadi di daerah sepanjang pantai Kecamatan Padang cermin dan Punduh Pedada, Kabupaten Pesawaran Propinsi Lampung. Sekitar 99.0\% dari total penderita Malaria di Pesawaran pada tahun 2010 berada di Kecamatan Padang Cermin dan Punduh Pedada. Tingginya kasus Malaria di kedua wilayah tersebut, selain karena faktor mobilitas penduduk yang tinggi, juga karena kondisi alam yang memungkinkan banyaknya tempat perindukan nyamuk seperti hutan, lagun dan tambak terlantar (Dinkes Pesawaran, 2011). Tempat perindukan yang lain selain tambak terlantar di Punduh Pedada adalah genangan-genangan air sebanyak 33 lokasi, rawa 24 lokasi dan bakau yang rusak 74 Ha (Ernawati, 2011).

Penelitian yang dilakukan di delapan desa endemis malaria di kecamatan Punduh Pedada, Kab. Pesawaran, Prov. Lampung pada tahun 
2010 menunjukkan bahwa 52,2 \% dari 414 jumlah sampel responden dari berbagai kelompok umur positif mengandung $P$. vivax (Ernawati, 2011). Hal ini perlu diwaspadai karena timbulnya Kejadian Luar Biasa (KLB) di Punduh Pedada sangat besar apabila tidak ada langkah penanggulangan yang tepat.

Pada siklus perkembanganbiakannya, nyamuk Anopheles membutuhkan tempat perindukan untuk bertelur. Tempat perindukan ini menjadi hal yang penting dalam proses kehidupan nyamuk dari jentik kemudian berkembang menjadi pupa. Kemudian pupa menjadi nyamuk dewasa terjadi di udara. Hanya tempat perindukan nyamuk yang mempunyai kriteria tertentu yang bisa menjadi tempat perindukan nyamuk Anopheles. Oleh karenanya, tempat perindukan nyamuk menjadi salah satu kunci analisa adanya kejadian malaria.

Penanganan tambak terlantar menjadi key altenative bagi pemberantasan malaria di kecamatan Punduh Pedada yang sebagian besar daerahnya merupakan desa-desa pesisir pantai. Untuk mengetahui penanganan yang tepat tambak terlantar agar tidak menjadi tempat perindukan nyamuk maka perlu diketahui akar permasalahan munculnya tambak terlantar. Oleh karenanya pada penelitian ini akan focus menggali akar permasalahan tambak terlantar sebagai tempat perindukan nyamuak malaria dan penanganannya.

\section{METODE PENELITIAN}

Penelitian ini dilakukan pada bulan Maret Juni 2012 di Kecamatan Punduh Pedada Kabupaten Pesawaran. Data yang digunakan adalah data primer dan sekunder. Pengumpulan data dilakukan dengan cara menyebarkan kuesioner ke masyarakat, wawancara mendalam (in dept interview), pengamatan (observasi), dan studi literatur.

Kuesioner masyarakat disebarkan di tiga desa lokasi penelitian. Data yang dikumpulkan menggunakan kuesioner adalah pendidikan, pendapatan dan peran serta masyarakat dalam hal pengelolaan lingkungan perindukan nyamuk.

Perhitungan jumlah responden menggunakan rumus (1). Populasi adalah Kepala Keluarga (KK) yang tinggal dekat tambak terlantar. Perhitungan sampel berdasarkan estimasi proporsi pada sampel acak sederhana. Jumlah sampel minimal dihitung dengan presisi mutlak sebesar $10 \%$ derajad kepercayaan 95\%. (C) 2012, Program Studi Ilmu Lingkungan Program Pasca Sarjana UNDIP
Bila p (proporsi) pengetahuan tentang malaria dan jumlah populasi diketahui maka jumlah sampel minimal dapat dihitung dengan menggunakan perhitungan Lemeshow (1997).

Rumus perhitungan sampel Lemeshow (1997):

$$
n=\frac{Z^{2}{ }_{1-\alpha / 2} p(1-p) N}{d^{2}(N-1)+Z^{2}{ }_{1-\alpha / 2} p(1-p)}
$$

Keterangan:

$\mathrm{n}=$ jumlah sampel minimal yang diperlukan

$\alpha=$ derajat kepercayaan

$\mathrm{p}=$ proporsi pada kelompok terpapar

$\mathrm{q}=1-\mathrm{p}$ (proporsi pada kelompok yang tidak terpapar)

$\mathrm{d}=$ limit dari error atau presisi absolut

Jika digunakan $\mathrm{p}$ (proporsi) sebesar 51,4\% hasil penelitian Ernawati et al (2011) tentang pengetahuan masyarakat baik tentang malaria di Punduh Pedada maka didapatkan hasil perhitungan sampel minimal adalah 67. Maka sampel untuk variabel pengetahuan dan perilaku masyarakat diambil minimal 67 orang tiap desa dan tiap responden mewakili satu keluarga. Cara pengambilan sampel ditetapkan dengan sistem acak sederhana, menggunakan kerangka sampel dari hasil pemetaan rumah yang tinggal dekat tempat perindukan vektor dengan radius $3 \mathrm{~km}$.

Wawancara mendalam (in-depth interview) dilakukan pada informan kunci yang terdiri dari tokoh masyarakat, aparat pemerintahan desa/kecamatan, staf dinas kesehatan, dinas perikanan dan dinas kehutanan Kabupaten Pesawaran. Wawancara terhadap tokoh masyarakat dan aparat desa/kecamatan bertujuan untuk menggali informasi yang mendalam tentang permasalahan tambak terlantar di masing-masing desa dan upaya desa/kecamatan dalam penanganan tambak terlantar serta kendala yang dihadapi.

Wawancara terhadap staf dinas kesehatan bertujuan untuk mendapatkan informasi tentang pelaksanaan pemberantasan malaria dan program-program yang dijalankan terutama terkait pengelolaan perindukan nyamuk.

Wawancara dengan dinas perikanan bertujuan untuk mendapatkan informasi tentang program yang dijalankan untuk menangani tambak terlantar di Punduh Pedada dan wawancara dengan dinas kehutanan bertujuan memperoleh informasi tentang permasalahan bakau yang dibabat dan dijadikan lahan tambak. Wawancara dilakukan selama 1-2 jam 
menyesuaikan dengan waktu luang yang dimiliki oleh informan.

Pengamatan bertujuan untuk mendapatkan data fenomena sosial hal-hal yang terkait tambak terlantar di lokasi penelitian. Selain itu, pengamatan bertujuan untuk melakukan pengecekan atas hasil wawancara. Studi literature diperoleh dari berita-berita di media cetak ataupun elektronik yang terkait dengan permasalahan tambak terlantar. Studi literature akan menunjang analisis akar permasalahan timbulnya tambak terlantar dan penanganannya.

\section{HASIL DAN PEMBAHASAN}

\section{Gambaran Lokasi Penelitian}

Kabupaten Pesawaran merupakan kabupaten/kota ke-11 di wilayah Provinsi Lampung. Kabupaten Pesawaran ini dibentuk berdasarkan Undang-Undang Nomor 33 Tahun 2007 tentang Pembentukan Kabupaten Pesawaran. Sebelumnya, Kabupaten Pesawaran ini menjadi bagian wilayah administrasi pemerintahan Kabupaten Lampung Selatan. Secara geografis, wilayah kerja Kabupaten Pesawaran berada diantara 50101 - 50501 Bujur Timur dan 1050101 - 1040201 Lintang Selatan.

Setelah menjadi daerah otonom, pada bulan Nopember 2007, Kabupaten Pesawaran memiliki luas wilayah kerja 1.173,77 $\mathrm{KM}^{2}$ atau 117,773 Ha. Pada tahun 2010 ini, wilayah kerja Kabupaten Pesawaran terbagi ke dalam 7 (tujuh) wilayah kerja Kecamatan, yaitu Tegineneng, Negeri Katon, Gedong Tataan, Way Lima, Kedondong, Padang Cermin, dan Punduh Pedada.

Batas wilayah Kecamatan Punduh Pedada, yaitu: sebelah utara berbatasan dengan wilayah Kecamatan Padang Cermin, Sebelah timur berbatasan dengan Teluk Ratai / Selat Sunda, Sebelah selatan berbatasan dengan kecamatan Kelumbayan Kabupaten Tenggamus, dan Sebelah barat berbatasan dengan kecamatan Kelumbayan Kabupaten Tenggamus dan Kecamatan Padang Cermin. Kecamatan Punduh Pedada terdiri dari 21 desa dan Sembilan desa diantaranya merupakan desa pantai, yaitu desa Kekatang, Kampung Baru, Pulau Pahawang, Sukarame, Kota Jawa, Rusaba, Sukamaju, Pager Jaya, dan Pulau Legundhi.

Punduh Pedada sebagian besar merupakan daerah perbukitan, pantai dan rawa yang menyebabkan sulitnya penataan lingkungan fisik di Punduh Pedada. Kondisi transportasi juga sangat buruk, karena sebagian jalan aspal sudah rusak berat dan sebagian besar masih berupa jalan tanah yang sulit dilewati terutama ketika hujan. Keadaan geografis daerah Punduh Pedada terdiri dari $42,5 \%$ berupa dataran, 39,5\% berupa dataran tinggi/perbukitan, $11,2 \%$ berupa lahan tambak, dan 6,8\% berupa daerah rawa-rawa. Wilayah pantai Punduh Pedada merupakan tempat bermuaranya sungai-sungai kecil dari arah perbukitan sehingga hampir setiap tahunnya sering terjadi bencana banjir bandang, terutama pada musim penghujan.

Daerah pantai dan rawa menarik dunia usaha untuk membuat tambak khususnya tambak udang. Tetapi para pengusaha kurang menyadari bahwa kolam tambak yang tidak terawat akan menjadi tempat perkembangan dan perindukan nyamuk malaria. Luas wilayah Punduh Pedada meliputi $24 \mathrm{Km}^{2}$ dengan jumlah penduduk 28.756 jiwa sehingga kepadatan penduduk mencapai 1.000 jiwa/ $/ \mathrm{Km}^{2}$. Tetapi kepadatan tidak merata dipengaruhi oleh keadaan geografis yang berbeda-beda. Pertumbuhan penduduk Pedada $\pm 2 \%$ /tahun. Distribusi penduduk tidak merata dan terkadang terpusat hanya pada satu perkampungan saja. Namun ada juga sebagian kecil penduduk yang tinggal di bukit-bukit sehingga menyulitkan pelayanan kesehatan.

\section{Akar Masalah Munculnya Tambak Terlantar Dan Menjadi Tempat Perindukan Nyamuk Anopheles}

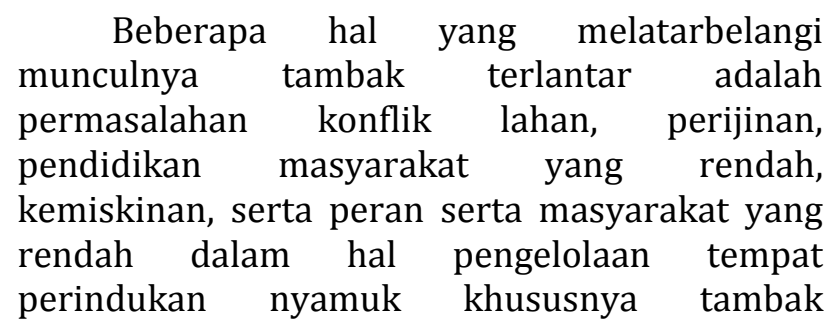
terlantar.

\section{Konflik lahan}

Berita adanya konflik lahan antara penduduk desa sekitar tambak dan pemilik tambak dimuat di media online Harian Lampung www.harianlampung.co.id, 24 Maret 2011. Di desa pantai Kekatang, konflik lahan terjadi karena pemilik tambak tidak membayar sewa lahan untuk jalan yang biasa dilalui oleh pengusaha tambak jika akan mengangkut udang. Selain itu konflik juga dipicu ada pengusaha 
tambak yang membeli lahan jalan. Padahal kesepakatan semula dengan sebagian penduduk desa, lahan jalan hanya boleh disewa tidak untuk dibeli.

Konflik lahan yang berakibat pemblokiran jalan sehingga akses untuk mengangkut hasil tambak tertutup, sebenarnya merupakan dampak dari akumulasi persoalan bahwa masyarakat desa tidak memperoleh keuntungan dengan adanya usaha tambak di desa mereka. Sebagaimana yang dikemukakan M. Nasir, kepala desa Kekatang, pada saat wawancara "Keberadaan usaha tambak udang itu sendiri tidak memberikan kontribusi apapun bagi desa.. Perusahaan udang itu sudah belasan tahun beroperasi, namun saya belum pernah merasakan bagaiamana rasanya udang ... Selain itu, perusahaan harusnya juga memiliki kepedulian untuk turut membangun desa".

Konflik ini membawa dampak semakin kuatnya kebersamaan sosial pada masyarakat desa pesisir. Ikatan dalam kelompok yang kuat memungkinkan munculnya kesadaran tentang identitas kelompok dan tumbuh rasa kebersamaan untuk mengejar tujuan bersama. Kondisi ini semakin memperbaiki kebersamaan sosial di kalangan masyarakat desa pesisir. Salah satu yang tampak nyata adalah kepedulian antar warga dan kebersamaan jika ada permasalahan yang diakibatkan oleh konflik.

\section{Ijin pembukaan lahan tambak}

Permasalahan ijin pembukaan lahan tambak juga menjadi salah satu penyebab lahan tambak terlantar. Sepuluh hektar hutan mangrove di Desa Sukarame, Kecamatan Punduh Pedada, Pesawaran Lampung habis dibabat untuk pembuatan tambak udang. pembabatan hutan mangrove itu tanpa pemberitahuan pada aparat desa setempat. Padahal pembukaan tambak seharusnya mendapat ijin dari kepala desa. (www.greenradio.fm, 7 April 2010)

Berdasarkan informasi yang disampaikan bapak Mursalim, Camat Punduh Pedada, Pada saat perpanjangan ijin operasi tambak, pemilik tambak tidak pernah datang saat diajak bermusyawarah oleh camat dan kepala desa setempat. Pemkab Pesawaran sendiri juga tidak tegas terhadap pengusaha tambak yang tidak memperpanjang ijinnya.

Pelaksanaan pemanfaatan ruang di wilayah pesisir telah banyak terjadi pelanggaran, misalnya pendirian bangunan dan atau pengusahaan tambak di sempadan pantai yang menyebabkan rusaknya hutan mangrove di jalur hijau (green belt). Belum adanya penyusunan rencana tata ruang wilayah pesisir berkaitan erat dengan belum adanya peraturan yang mendukung secara tegas upaya penataan ruang wilayah pesisir tersebut. Hal ini ternyata merupakan salah satu pemicu terjadinya konflik kepentingan yang berkepanjangan. Konflik kepentingan terjadi antara sektor kehutanan dengan perikanan yang berhubungan dengan pemanfaatan jalur hijau untuk tambak (Pemda Propinsi Lampung, 2010).

\section{Rendahnya pendidikan masyarakat}

Gambaran pendidikan respoden di tiga desa yaitu Sukarame, Sukamaju, dan Kampung Baru (tabel 1) memperlihatkan bahwa mayoritas responden yang berjumlah 210 orang di tiga desa berpendidikan sekolah dasar (Sukarame sebanyak 21 orang, Sukamaju dan Kampung Baru sebanyak 33 orang).

Tabel 1. Distribusi Responden Berdasarkan Tingkat Pendidikan di Masing-masing Desa

\begin{tabular}{cccc}
\hline \multirow{2}{*}{ Pendidikan } & \multicolumn{3}{c}{ Desa } \\
\cline { 2 - 4 } & Sukarame & Sukamaju & $\begin{array}{c}\text { Kampung } \\
\text { Baru }\end{array}$ \\
\hline Tidak Sekolah & 8 & 0 & 7 \\
& $11.4 \%$ & $0.0 \%$ & $10.0 \%$ \\
Tidak Tamat & 21 & 33 & 33 \\
SD/SD & $30.0 \%$ & $47.1 \%$ & $47.1 \%$ \\
Tidak Tamat & 17 & 21 & 16 \\
SMP/SMP & $24.3 \%$ & $30.0 \%$ & $22.9 \%$ \\
& & & \\
Tidak Tamat & 8 & 11 & 5 \\
SMA/SMA & $11.4 \%$ & $15.7 \%$ & $7.1 \%$ \\
Diploma/PT & 16 & 5 & 9 \\
\hline
\end{tabular}

Gambaran pendidikan ini hampir sama dengan pendidikan penduduk secara keseluruhan di Kabupaten Pesawaran. Mayoritas penduduk kabupaten Pesawaran berpendidikan tidak/belum tamat SD (20.9\%), tamat SD/MI (32.8\%), dan tamat SLTP/MTs (25.6\%) (Profil Kesehatan Kabupaten Pesawaran, 2011).

Gambaran rendahnya pendidikan masyarakat daerah pesisir juga dicantumkan dalam Renstra (Rencana Strategis) Pengelolaan Wilayah Pesisir Lampung tahun 2010, bahwa isu prioritas wilayah pesisir Lampung salah satunya karena rendahnya kualitas sumberdaya manusia.

Pendidikan merupakan proses untuk menjadi manusia yang berlangsung dalam ruang, waktu dan lingkungan tertentu sehingga 
pendidikan tidak bisa menafikan aspek budaya. Oleh karena itu, menurut HAR Tilaar (2004) pendidikan dan budaya merupakan satu kesatuan eksistensial. Lebih jauh ia menambahkan, pendidikan dalam konteks kebudayaan berhubungan dengan konsep kekuasaan. ekuasaan dalam hal ini adalah kemampuan manusia untuk berbuat sesuatu yang lain dari yang lain. Berangkat dari sini, pendidikan dapat memiliki daya tawar untuk melakukan perubahan, termasuk mengubah cara pandang masyarakat terhadap kemiskinan hidupnya juga permasalahan kesehatan seperti penyakit malaria.

Jika dihubungkan dengan konflik lahan tambak yang terjadi di Punduh Pedada, maka menurut Tilaar (2004) bahwa masyarakat Indonesia adalah masyarakat multikultural sebenarnya menyimpan banyak kekuatan, sekaligus menyimpan benih perpecahan jika tidak dikelola dengan baik dan rasional. Sehingga diperlukan upaya menanamkan kesadaran multikulturalisme kepada semua lapisan masyarakat. Pandangan Tilaar mengenai pendidikan multikultural adalah merupakan proses pengembangan sikap dan tata laku seseorang atau sekelompok orang dalam usaha mendewasakan manusia melalui upaya pengajaran, pelatihan, proses, perbuatan, dan cara-cara mendidik yang menghargai pluralitas dan heterogenitas secara humanistik. Pendidikan adalah sebuah konsep, ide atau falsafah sebagai suatu rangkaian kepercayaan (set of believe) dan penjelasan yang mengakui dan menilai pentingnya keragaman budaya dan etnis di dalam membentuk gaya hidup, pengalaman sosial, identitas pribadi, kesempatan-kesempatan pendidikan dari individu, kelompok maupun negara.

\section{Rendahnya pendapatan masyarakat atau kemiskinan}

Gambaran pendapatan warga (tabel 2) menunjukkan bahwa mayoritas penduduk di desa Sukarame dan Kampung Baru memiliki pendapatan di bawah Rp500.000,- yaitu sebanyak 35 orang dan 43 orang. Sementara di Sukamaju sebagian besar berpenghasilan antara Rp500.000,- sampai 1.000.000,- sebanyak 45 orang.

Penduduk miskin adalah penduduk yang memiliki rata-rata pengeluaran per kapita per bulan dibawah Garis Kemiskinan. Berdasarkan data statistic (2006), garis kemiskinan selama
Maret 2007-Maret 2008, garis kemiskinan naik sebesar 9,567 persen, yaitu dari Rp.166.697,- per kapita per bulan pada Maret 2007 menjadi Rp.182.636,- per kapita per bulan pada Maret 2008. Jika pendapatan total penduduk Punduh Pedada sebagian besar hanya Rp. 500.000,/bulan maka pendapatan perkapita adalah Rp. 125.000,- per kapita per bulan (dengan asumsi jumlah anggota keluarga adalah 4 orang tiap keluarga). Angka tersebut masih jauh dibawah angka kemiskinan yang ditetapkan oleh BPS.

Tabel 2. Distribusi Responden Berdasarkan Pendapatan di Masing-Masing Desa

\begin{tabular}{cccc}
\hline \multirow{2}{*}{ Pendapatan } & \multicolumn{3}{c}{ Desa } \\
\cline { 2 - 4 } & Sukarame & Sukamaju & $\begin{array}{c}\text { Kampung } \\
\text { Baru }\end{array}$ \\
\hline < Rp. 500.000 & 35 & 19 & 43 \\
& $50.0 \%$ & $27.1 \%$ & $61.4 \%$ \\
Rp. 500.000 & 21 & 45 & 18 \\
Rp. 1.000.000 & $30.0 \%$ & $64.3 \%$ & $25.7 \%$ \\
Rp. 1.000.000 & 8 & & 7 \\
Rp. 2.000.000 & $11.4 \%$ & $5.7 \%$ & $10.0 \%$ \\
Rp. 2.000.000 & 5 & & 2 \\
Rp. 3.000.000 & $7.1 \%$ & $.0 \%$ & $2.9 \%$ \\
> Rp. 3.000.000 & $1.4 \%$ & $2.9 \%$ & 0 \\
\hline
\end{tabular}

Masyarakat yang berada kawasan pesisir menghadapi berbagai permasalahan yang menyebabkan kemiskinan. Pada umumnya mereka menggantungkan hidupnya dari pemanfaatan sumberdaya laut dan pantai yang membutuhkan investasi besar dan sangat bergantung musim. Sebagian besar dari mereka bekerja sebagai nelayan kecil, buruh nelayan, pengolah ikan skala kecil dan pedagang kecil karena memiliki kemampuan investasi terbatas. Petani tambak yang berasal dari Punduh Pedada rata-rata merupakan pekerja bukan pemilik tambak. Pemilik tambak adalah orang luar yang mempunyai modal yang besar.

\section{Peran serta masyarakat dalam pengelolaan tambak terlantar}

Peran serta masyarakat tentang pengelolaan tambak terlantar di tiga desa (tabel 3) sebagian besar kategori sedang (Sukarame 56 orang, Kampung Baru 57 orang, Sukamaju 65 orang). Peran serta masyarakat dalam 
penanganan tambak terlantar pada penelitian adalah ikut membantu membersihkan ganggang atau lumut pada tambak yang tidak produksi, ikut membantu menebarkan ikan pada tambak yang tidak produksi, melaporkan kepada petugas dinas kesehatan tentang keberadaan tambak terlantar, melaporkan kepada aparat desa tentang keberadaan tambak terlantar, dan memberi saran kepada pemilik tambak agar mengelola tambaknya sehingga tidak lagi menjadi tempat perindukan nyamuk Anopheles. Peran serta termasuk kategori baik jika responden bisa memilih jawaban berdasarkan aktivitas yang dilakukannya sebesar lebih dari $80 \%$. Sedang jika jawaban responden adalah 60 $80 \%$. Dan kurang jika jawaban responden adalah kuang dari $60 \%$.

Tabel 3. Peran Serta Masyarakat tentang pengelolaan tambak terlantar di Masing- Masing Desa

\begin{tabular}{lccc}
\hline Peran Serta & \multicolumn{3}{c}{ Desa } \\
\cline { 2 - 4 } Masyarakat & Sukarame & Sukamaju & $\begin{array}{c}\text { Kampung } \\
\text { Baru }\end{array}$ \\
\hline Baik & 8 & 3 & 3 \\
& $11.9 \%$ & $4.4 \%$ & $4.8 \%$ \\
Sedang & 56 & 65 & 57 \\
& $83.6 \%$ & $95.6 \%$ & $91.9 \%$ \\
Buruk & 3 & 0 & \\
& $4.5 \%$ & $0.0 \%$ & $3.2 \%$ \\
\hline
\end{tabular}

\section{Penanganan Tambak Terlantar}

\section{Persepsi tentang pentingnya menangani tambak terlantar sangat menentukan}

Faktor yang cukup penting pula dalam pengelolaan tambak terlantar agar tidak lagi menjadi tempat perindukan nyamuk malaria adalah pandangan/persepsi masyarakat di suatu daerah terhadap penyakit malaria dan vektor malaria. Apabila malaria dianggap sebagai suatu kebutuhan (demand) untuk diatasi, upaya untuk menyehatkan lingkungan akan dilaksanakan oleh masyarakat secara spontan atau dengan kata lain peran serta masyarakat akan tinggi dalam mengelola lingkungan perindukan nyamuk Anopheles.

Persepsi positif tersebut sebenarnya bisa dibangun oleh semua pihak atau stakeholder, jika menyadari bahwa tanggungjawab pengelolaan lingkungan tambak terlantar adalah bentuk tanggung jawaban generasi masa kini terhadap generasi masa datang. Lester L. Brown (1981)

(C) 2012, Program Studi Ilmu Lingkungan Program Pasca Sarjana UNDIP dalam buku Building a sustainable Society mengatakan bahwa:

"We have not inherited the earth fromour fathers, we are borrowing it fromour children"

(Kita tidak mewarisi lingkungan dari orang tua kita, tetapi kita meminjam lingkungan hidup tersebut dari anak kita).

Mengelola tambak terlantar agar tidak lagi menjadi tempat perindukan nyamuk Anopheles sebenarnya sangat banyak keuntungannya tidak hanya memutuskan rantai penularan malaria. Tetapi juga sangat efisien karena dapat digabungkan dengan pengendalian penyakit tular vector yang berkaitan dengan air sebagai tempat berkembang biak, bersifat jangka panjang, relatif berbiaya rendah dalam jangka panjang, dapat diintegrasikan dengan program pengembangan infrastruktur, mengurangi dampak lingkungan, relatif aman bagi pekerja dibandingkan jika pekerja menggunakan insektisida untuk memberantas nyamuk Anopheles (Depkes, 2007).

\section{Tempat perindukan tambak terlantar adalah tanggung jawab semua pihak}

Berdasarkan wawancara dengan ibu Endang, Kadinkes Pesawaran, pada tanggal 24 Mei 2012 dikemukakan bahwa "kasus malaria meningkat salah satunya adalah tidak adanya dukungan dari sektor yang lain. Masyarakat menganggap malaria bukan masalah serius. Sehingga jika ada masyarakat yang terkena malaria, tidak segera memeriksakan dirinya ke layanan kesehatan yang menyebabkan penularan malaria semakin tinggi. Hal ini diperparah lagi dengan kurangnya perhatian dari sector lain seperti dinas perikanan, dinas kehutanan, dinas pendidikan, dinas $P U$ dan lain sebagainya".

Dukungan lintas sector dalam permasalahan malaria merupakan keniscyaan. Fenomena malaria adalah sebuah peristiwa 'kontinum' yakni peristiwa yang berkesinambungan (Achmadi, 2012). Seseorang menderita sakit karena adanya kontak dengan lingkungan, agen berproses dalam tubuh yang pada akhirnya pergulatan melawan penyakit hasil akhirnya adalah kondisi sakit atau tetap sehat. Fenomena kontinum tersebut ada dalam suatu wilayah permukaan bumi. Demikian dengan malaria. Kejadian malaria adalah peristiwa kontinum yang mau tidak mau jika ingin memberantasnya kita harus melihat ruang 
atau wilayah dimana penyakit malaria tersebut timbul.

Penyakit malaria bisa dikatakan sebagai penyakit yang bersifat spesifik local, yang artinya sangat tergantung pada kondisi local daerah. Karena perilaku nyamuk Anopheles sebagai vector malaria juga berbeda-beda pada tiap wilayah. Meskipun demikian, malaria juga bisa dikatakan penyakit yang bersifat global. Tempat perindukan nyamuk Anopheles tidak hanya menjadi tanggung jawab kepala daerah pada unit terkecil. Karena kadang perindukan nyamuk bisa melewati batas wilayah desa, kecamatan, bahkan propinsi. Sifat global dalam transmisi malaria maka penyelesainnya membutuhkan keterpaduan seluruh stakeholder.

Achmadi (2012) mengemukakan dalam bukunya bahwa manajemen penyakit berbasis wilayah harus dilakukan secara terpadu sejak dari perencanaan, pelaksanaan, pembiayaan maupun monitoring pelaksanaannya. Demikian juga dengan pengelolaan perindukan tambak terlantar. Integrated harus dilaksanakan pada semua tahapan kegiatan pengendalian penyakit malaria. Misalnya, pada tahap pencegahan maka keterpaduan bisa diterapkan pada program penyuluhan baik yang dilaksanakan oleh dinas kesehatan maupun instansi lainnya. Dari aspek kesehatan selain menjelaskan gejala dan pengobatan malaria juga perlu dijelaskan tentang potensi tempat perindukan nyamuk dan bahayanya. Sedangkan dari dinas kehutanan misalnya, perlu menjelaskan tentang dampak akibat mangrove dibabat dan keuntungannya jika melestarikan mangrove. Juga dari sisi hukum menjelaskan tentang Undang-undang yang terkait dan penegakan hukum. Perlu juga disampaikan tentang rencana tata ruang wilayah pesisir dalam Rencana Tata Ruang Wilayah Kabupaten (RTRWK) dan Rencana Tata Ruang Wilayah Propinsi (RTRWP). Program penyuluhan akan berhasil baik jika ada keterpaduan sejak dari perencanaan, pelaksanaan, pembiayaan maupun monitoring pelaksanaannya.

Pengelolaan tambak terlantar agar tidak menjadi tempat perindukan merupakan program lintas sektor yang melibatkan berbagai instansi. Selain itu juga membutuhkan dana yang besar. Karena banyak pihak yang terlibat dan memerlukan dana besar maka political will pemerintah sangat menentukan. Tanpa dukungan dan keterlibatan semua pihak maka kegiatan pengelolaan tambak terlantar tidak akan berkelanjutan atau bisa dibilang hanya kegiatan yang bersifat sementara.

\section{Belajar dari penebaran ikan nila pada lahan tambak terlantar di desa Sidodadi}

Pada tahun 2011, kegiatan penanganan tambak terlantar di desa Sidodadi, kecamatan Padang Cermin, Kabupaten Pesawaran adalah pengangkatan lumut dan penebaran ikan predator ikan nila. Pada kegiatan pengangkatan lumut melibatkan kader malaria dengan penanggung jawab kegiatan adalah Lembaga Swadaya Masyarakat (LSM) Forum Peduli Malaria. Sedangkan kegiatan penebaran ikan melibatkan kader malaria dan masyarakat dengan penanggung jawab Dinas Perikanan Kabupaten Pesawaran. Kegiatan penebaran ikan 10.000 ekor pada tambak terlantar di desa Sidodadi merupakan program lintas sektor antara Dinas Perikanan dengan Dinas Kesehatan. Setelah ada program pengangkatan lumut atau pembersihan ganggang dan penebaran ikan, kasus malaria klinis dan positif plasmodium terlihat menurun. Selain penanganan tambak terlantar, program pengendalian malaria yang lain yang dijalankan adalah Indoor Residual Spraying (IRS), mass blood survey, larvaciding, penanaman bakau,dan gerakan jum'at bersih. Meskipun sebenarnya juga perlu diteliti lebih lanjut apakah kasus malaria turun benar-benar dikarenakan penanganan tambak terlantar (Ernawati, 2011).

\section{Perlunya pemberdayaan masyarakat dalam menangani tambak terlantar}

Peran serta aktif masyarakat juga sangat diharapkan pada program pengelolaan perindukan tambak terlantar. Dengan keterlibatan masyarakat, ada jaminan untuk keberlanjutan kegiatan karena masyarakat bisa ikut serta memonitor kegiatan atau sekaligus menjadi pelaksananya.

Informasi yang disampaikan oleh Bapak Suparno Sagita, kasie penangkapan dinas Perikanan Kabupaten Pesawaran bahwa menghidupkan tambak kembali bukanlah hal yang mudah. Banyak faktor yang mempengaruhinya. Selain ketersediaan dana, SDM, juga teknologi. Kendala pada program pemberdayaan masyarakat untuk penebaran ikan predator seperti ikan nila merah pada kolam-kolam tambak yang tidak produksi tidak mudah. Meskipun dari sisi SDM tidak masalah dengan keterlibatan aktif masyarakat, tetapi dari 
sisi teknologi tentang budidaya ikan baik ikan nila merah maupun ikan Bandeng yang tidak gampang. Membutuhkan teknologi adanya arus air pada tambak. Ketersediaan teknologi ini meskipun pada awalnya mendapatkan bantuan dari dinas Perikanan tetapi pada pelaksanaannya jika ada kendala pada teknologi tersebut, masyarakat tidak bisa dengan segera menyelesaikannya. Masyarakat sering bersikap pasif dan tidak ada upaya untuk menyelesaikan sendiri persoalan tersebut (Ernawati, 2011).

Pada konsep pemberdayaan masyarakat, pemberdayaan dapat diartikan sebagai upaya untuk menolong yang lemah atau tidak berdaya (powerless) agar mampu (berdaya) baik secara fisik, mental dan pikiran untuk mencapai kesejahteraan sosial hidupnya. Dalam konteks ini, mereka dipandang sebagai aktor yang mempunyai peran penting untuk mengatasi masalahnya. Menurut Mujiyadi dan Gunawan (2000), pemberdayaan merupakan suatu proses peningkatan kondisi kehidupan dan penghidupan yang ditujukan kepada masyarakat miskin. Masyarakat miskin memerlukan "penguatan" agar mampu memanfaatkan daya (power) yang dimilikinya. Dalam rangka pemberdayaan, masyarakat membutuhkan bantuan tidak hanya dari segi ekonomi tetapi juga segi immateriiil.

Pemberdayaan masyarakat dalam menangani tambak terlantar membutuhkan dukungan pemerintah. Terdapat empat unsur pokok pengembangan masyarakat yaitu adanya tujuan yang akan dicapai, organisasi masyarakat, partisipasi masyarakat, dan dukungan pemerintah. Insistaf mengembangkan masyarakat dalam menangani tambak terlantar diharapkan dapat berasal dari dalam masyarakat sehingga peran orang luar lebih banyak sebagai fasilitator.

\section{KESIMPULAN DAN REKOMENDASI}

Akar permasalahan adanya tambak terlantar sehingga menjadi tempat perindukan nyamuk malaria adalah adanya konflik lahan, masyarakat desa tidak merasa diuntungkan dengan adanya usaha tambak, perijinan tambak yang bermasalah, pendidikan masyarakat yang rendah, kemiskinan serta peran serta masyarakat yang kurang.

Hal terpenting dari penanganan tambak terlantar adalah kesadaran seluruh individu bahwa malaria merupakan permasalahan yang serius dan penanganan tambak terlantar merupakan keniscyaan untuk memutuskan rantai penularan penyakit. Selain menghidupkan tambak terlantar dengan budi daya udang kembali, juga bisa menggantinya dengan budi daya ikan nila yang membutuhkan modal tidak sebesar budi daya udang. Kerjasama lintas sector, integrated, dan sustainability menjadi prinsip dalam penanganan tambak terlantar.

\section{UCAPAN TERIMA KASIH}

Terima kasih kepada DRPM Universitas Indonesia yang telah memberikan kepercayaannya kepada tim peneliti untuk melaksanakan penelitian Malaria ini dengan pendanaan Hibah Riset Madya Universitas Indonesia gelombang 1 tahun 2012.

\section{DAFTAR PUSTAKA}

Achmadi UF, 2009, Horison Baru Kesehatan Masyarakat Di Indonesia. Penerbit Rineka Cipta. Jakarta.

Achmadi UF, 2012, Manajemen Penyakit Berbasis Wilayah, Seri Desentralisasi Kesehatan Masyarakat. Edisi Revisi. Rajawali Press. Jakarta.

Antara News Lampung, Tambak Terlantar Penyebab Tingginya Penyebaran Malaria http://hileud.com/hileudnews?title=Tamb ak+Terlantar+Penyebab+Tingginya+Penye baran+Malari... Selasa, 24 Agustus 2010 04:16 WIB di download pada 05/06/2011 pukul 18:01

Badan Pusat Statistik, 2008, Penduduk Muskin (Poor Population). Berita Resmi Statistik No. 37/07/Th. XI, 1 Juli 2008

Brown LR, 1981, Building a sustainable Society Worldwatch, Institute Book, WW Horion \& Company, New York.

Clive, S. 2002, Integrated Approach to malaria control. Clinical Microbiology Reviews. Vol.15.no.2. p: 278-293. http://cmr.asm.org/cgi/content/full/15/2/ 278\#SUMMARY, 04/02/2011, pk. 15:37 WIB.

Departemen Kesehatan RI, 2007, Pedoman Pemberantasan Vektor, Dirjen P2PL P2B2. Depkes.

Departemen Kesehatan RI, 2009, Keputusan Menteri Kesehatan RI No. 293/MENKES/SK/IV/2009. 28 April 2009 
Tentang Eliminasi Malaria Di Indonesia. Dirjen P2PL. Depkes.

Dinkes Kab. Pesawaran. 2011. Profil Kesehatan Kabupaten Pesawaran 2010, Gedong Tataan - Pesawaran Lampung.

Ernawati K, Achmadi UF, Soemardi TP, Thayyib H, Asteria D, dan Wulansari R, 2011, Stratregi Efektif Mencegah Malaria Dengan Kampanye Pengelolaan Lingkungan Perindukan Vektor, Prosiding Konferensi Nasional Komunikasi, "Membumikan Ilmu Komunikasi di Indonesia, Depok, 9-10 Nov 2011, ISBN: 978-602019283-0-1

Ernawati K, Setyaningrum E, Jannah F, Dewi C dan Mardliyah D, 2011, Dampak Pengelolaan Lingkungan Perindukan Vektor Malaria Terhadap Pengendalian Kasus Malaria Di Daerah Endemis, Prosiding Seminar Nasional Sains dan Teknologi ke IV Unila "Peran Strategis Sains \& Teknologi Dala Membangun Karakter Bangsa", Bandar Lampung 29-30 Nopember 2011, di Unila, ISBN: 978-979-8510-34-2

Ernawati K, Achmadi UF, Soemardi TP, Thayyib H, dan Setyaningrum E, 2011, Potensi Tambak Terlantar sebagai Tempat Perindukan Vektor Malaria Serta Kemungkinan Pengendaliannya, Prosiding Seminar Nasional Sains dan Teknologi ke IV Unila "Peran Strategis Sains \& Teknologi Dala Membangun Karakter Bangsa", Bandar Lampung 29-30 Nopember 2011, di Unila, ISBN: 978-979-8510-34-2

Ernawati K, Soesilo B, Duarsa A, Rifqatussa'adah, 2011, Hubungan Faktor risiko Individu dan Lingkungan Rumah Dengan Malaria Di Punduh Pedada Kabupaten Pesawaran Propinsi Lampung, Jurnal Makara Seri Kesehatan, Edisi Desember 2011. Jakarta.

Githeko AK and Warnell DA, 2001, Predicting Malaria Epidemics in the Kenyan Highlands using Climate Data: A Tool for Decision Markers, Global Change \& Human Health. Vol. 2 No. 1.

Green Radio Fm, 7 April 2010, Mangrove Dibabat Untuk Tambak Udang.

http://www.greenradio.fm/news/latest/2 667-mangrove-dibabat-untuk-tambakudang 1 of 3. Download pada 13/06/2011 pukul 21:25

Green Radio Fm, 13 April 2010, Tambak Udang Pesawaran Ijinnya Sudah Habis. http://www.greenradio.fm/news/latest/2 708-tambak-udang-pesawaran-ijinnya sudah-habis. 1 of 3 . Download pada 13/06/2011 pukul 21:11

Harian Lampung, 24 Maret 2011, Warga Kekatang Blokir Jalan.

http://www.harianlampung.co.cc/2011/0

3/warga-kekatang-blokir-jalan.html 1 of 5 . Download pada 13/06/2011 pukul 21:28

Lemeshow S and David WH Jr, 1997, Besar Sampel dalam Penelitian Kesehatan (terjemahan), Gadjahmada University Press, Yogyakarta.

Mujiyadi B dan Gunawan, 2000, Pemberdayaan Masyarakat miskin (Suatu Kajian terhadap Masyarakat di Sekitar Kawasan Industri) dalam Informasi Vol .5 No. 1 Januari 2000. Balitbang Depsos RI. Jakarta.

Pemda Propinsi Lampung, 2000, Rencana Strategis Pengelolaan Wilayah Pesisir Lampung. Kerjasama Pemerintah Daerah Propinsi Lampung dengan Proyek Pesisir Lampung dan PKSPL - IPB. Bandar Lampung. Indonesia

Penilaian Kinerja Puskesmas Punduh Pedada Tahun 2009. Puskesmas Pedada. Dinkes Kab. Pesawaran.

Sutisna P, 2004, Malaria Secara Ringkas. EGC. Jakarta

Tilaar HAR, 2004, Multikulturalisme, Tantangantantangan Global Masa Depan dalam Transformasi Pendidikan Nasional, Jakarta; Grasindo. 